\title{
Long-term results of corneal wedge resections for the correction of high astigmatism
}

\author{
V.P.T. HOPPENREIJS, G. VAN RIJ, W.H. BEEKHUIS, \\ W.J. RIJNEVELD \& E. RINKEL-VAN DRIEL \\ Department of Ophthalmology, Erasmus University, Eye Hospital, Rotterdam, The \\ Netherlands
}

Accepted 18 July 1990

Key words: Cornea, astigmatism, astigmatic correction, wedge resection, keratoplasty

\begin{abstract}
We retrospectively evaluated 41 corneal wedge resections, performed for the correction of high astigmatism in 40 patients who were spectacle and contact lens intolerant. Keratometric astigmatism decreased from an average of 11.7 diopters (range 5 to 22.5 D) preoperatively to 3.5 diopters (range 0 to $10 \mathrm{D}$ ) postoperatively, representing a mean reduction of $8.2 \mathrm{D}$ (range 0 to 16.5 ), or $70 \%$. The length of follow-up averaged 11 months. Twenty-five, 15 and 9 cases had a follow-up of at least 3,5 and 10 years, respectively. In 16 cases the keratometry readings remained stable over the years. However, in 1 case of Fuchs' endothelial dystrophy (follow-up 13 years) and 5 cases of keratoconus (follow-up 3, 4, 12, 13 and 14 years) the astigmatism gradually increased during the various follow-up periods. In 3 other cases the astigmatism gradually decreased over the years. Corneal wedge resection is an effective technique for managing high corneal astigmatism. The results remain stable over the years except in some patients with keratoconus.
\end{abstract}

\section{Introduction}

Thanks to improvements in microsurgical and eye banking technology, the chance of a successful longtime clear graft after penetrating keratoplasty has improved markedly. However, the final goal for both surgeon and patient is good visual acuity. Good vision is not always achieved when high residual astigmatism accompanies an otherwise clear and physiologically successful graft. Even when various techniques designed to reduce postoperative astigmatism, such as donor punches, intraoperative keratometry, and selective postoperative suture removal, are used, a significant number of these cases still arise. A clear graft with high astigmatism is often interpreted by the patient as a bad result. If high residual corneal astigmatism cannot be managed successfully with glasses or contact lenses, a surgical approach may be indicated. A number of approaches for the surgical reduction of 
astigmatism after keratoplasty have emerged, all with variable success [1-15].

Relaxing incisions [1-8] and wedge resections [6-12] are probably the most common procedures currently performed. The use of relaxing incisions, performed in the axis of the steeper meridian under the slit lamp on routine outpatient visits, is a simple technique with fast recovery, but corrects the astigmatism to a lesser degree than wedge resections. The addition of compression sutures in the flat axis has been used to augment the effect obtained by relaxing incisions [13, 14]. Recently, Limberg et al. described the use of compression sutures alone for the reduction of astigmatism after penetrating keratoplasty [15]. A wedge resection comprises the resection of a wedge of tissue inside, encompassing, or outside the graftrecipient scar in the flat axis, followed by the placement of multiple sutures. It can correct larger degrees of astigmatism but the recovery period is long. The aim of this study was to determine the effectiveness of corneal wedge resections during a long period of time. As far as we know, a follow-up of ten years or more has not been described before.

\section{Materials and methods}

We retrospectively reviewed 42 consecutive patients, who underwent corneal wedge resection at the Eye Hospital in Rotterdam between November 1974 and June 1989. Wedge resections were performed on all patients with high astigmatism who were unable to wear glasses or contact lenses. The results of astigmatism correction in the first 17 patients with a short follow-up period have been described before [10]. Two patients were lost to follow-up and were excluded. The study reports on the remaining 40 patients. Wedge resections were performed after: penetrating keratoplasty (32 patients), lamellar keratoplasty (4 patients), corneal perforation ( 2 patients), radial keratotomy (1 patient) and lipoid cornea dystrophy in 1 patient. The initial corneal diseases are listed in Table 1.

Patients' ages at the time of wedge resection ranged from 7 to 83 years (mean age 53 years). There were 26 females and 14 males in our group. The refractive state of the patients was followed by refraction and keratometry. All patients had stable keratometry readings. During the operation we identified the steep and flat corneal meridians with a contact keratoscope, an $18 \mathrm{~mm}$ diameter cylindrical device that is placed on the globe and projects concentric rings over the graft and host cornea, including the limbal area [16]. The wedge resection was performed at the flatter end of the flat corneal meridian. 
Table 1. Initial diagnosis.

\begin{tabular}{lr|lc}
\hline Diagnosis & $\begin{array}{l}\text { Number } \\
\text { of eyes }\end{array}$ & Diagnosis & $\begin{array}{l}\text { Number } \\
\text { of eyes }\end{array}$ \\
\hline Keratoconus & $13(32.5 \%)$ & Bullous keratopathy & $1(2.5 \%)$ \\
Interstitial keratitis & $8(20.0 \%)$ & Terrien's marginal degeneration & $1(2.5 \%)$ \\
Herpetic keratitis & $5(12.5 \%)$ & Reis-Bücklers' dystrophy & $1(2.5 \%)$ \\
Corneal scar (trauma) & $5(12.5 \%)$ & Cornea dystrophy (lipoid) & $1(2.5 \%)$ \\
Fuchs' endothelial dystrophy & $4(10.0 \%)$ & Radial keratotomy & $1 /(2.5 \%)$ \\
& & & $40(100 \%)$ \\
\hline
\end{tabular}

From 1974 to 1979 , we used the technique described by Troutman [1]; the wedge resection was performed with a $30^{\circ}$ razor-blade knife (12 wedge resections). From 1979 to 1984 we used a V-shaped knife (8 wedge resections) [10]. After 1984 sharp V-shaped knives were no longer available and a $30^{\circ}$ razor-blade knife was used again ( 21 wedge resections). The wedge resection was taken outside the graft-recipient scar or encompassed it. Where there was wound slippage or elevation, the resection was made in the sector of the wound disturbance. The length of the incision, centered on the axis of the flatter meridian, was approximately $60-90^{\circ}$ of the graft circumference. The depth was approximately $90 \%$ of the corneal thickness. The width at the center of the wedge varied from 0.1 to $0.8 \mathrm{~mm}$, depending on the amount of preoperative astigmatism to be corrected and on the presence or absence of wound override (graft elevation). If graft elevation existed less tissue was removed. Sometimes slight graft elevation could only be observed after removing the epithelium covering the graft-recipient interface. Over the years the size of the wedge resections made became smaller. The anterior chamber was entered in the central part of the wedge with the razor-blade knife, then the anterior chamber was refilled with a balanced salt solution and air. The wound was closed with 6 to 8 interrupted 10-0 nylon sutures. The immediate surgical goal was to overcorrect the preoperative astigmatism to a degree approximately equal to the original cylinder, with a $90^{\circ} \mathrm{shift}$ in axis.

Postoperatively, the patients received a regimen of topically applied antibiotics and corticosteriods. Numerous postoperative visits were required, beginning one week postoperatively. During the follow-up visits, corneal curvature readings were obtained and the wound was examined under the slit lamp. By judicious suture removal, we attempted to titrate the amount of residual astigmatism toward the ideal endpoint of a spherical cornea. Sutures were first removed between 4 weeks and several months postoperatively. In some cases a few sutures were left in place for more than one year. Spectacles or contact lenses were used for final optical correction. 
In 2 patients a complementary relaxing incision in the steep axis was required, after 3 and 7 months respectively, to reduce the residual corneal astigmatism. One patient underwent a second wedge resection after 6.5 years.

The short-term results of 41 wedge resections, performed in 40 patients, are given after an average follow-up of 11 months. Twenty-four patients (with 25 wedge resections) reached a follow-up of 3 years or more. The follow-up was 5 years or more in 14 patients ( 15 wedge resections) and 10 years or more in 9 patients.

\section{Results}

Short-term results

The interval between the primary operation and the corneal wedge resection averaged 43.1 months (range, 7 months to 18 years). The mean corneal astigmatism before wedge resection was 11.7 diopters (range, 5 to $22.5 \mathrm{D}$ ). Following wedge resection, the residual corneal astigmatism averaged 3.5 diopters (range, 0 to $10 \mathrm{D}$ ) after a mean follow-up of 11 months (range, 5 to 24 months). The average reduction of astigmatism amounted to 8.2 diopters (range, 0 to $16.5 \mathrm{D}$ ), which represents a decrease of $70 \%$ of the preoperative value (Table 2).

The net change in spheroequivalence was measured by keratometry by subtracting the average preoperative keratometric reading from the average postoperative keratometric reading. The mean spheroequivalent change was a hyperopic postoperative shift of 1.02 diopters with a range of -6.45 to +5.39 diopters. Six corneas were steeper after wedge resection, 25 were flatter, and 9 were essentially unchanged $(-0.5$ to $+0.5 \mathrm{D})$ (Unkown $1 \mathrm{x})$.

Table 2. Short-term results of 41 corneal wedge resections (40 patients).

\begin{tabular}{lrc}
\hline $\begin{array}{l}\text { Mean astigmatism } \\
\text { preoperative } \\
\text { postoperative } \\
\text { change }\end{array}$ & $11.7 \mathrm{D}$ & $(5-22.5 \mathrm{D})$ \\
Mean follow-up 11 mos $(5-24 \mathrm{mos})$ & $3.5 \mathrm{D}$ & $(0-10.0 \mathrm{D})$ \\
$\begin{array}{l}\text { Mean keratometry } \\
\text { (steep + flat axis)/2] }\end{array}$ & & $(0-16.5 \mathrm{D})$ \\
$\quad$ & \\
$\begin{array}{l}\text { preoperative } \\
\text { postoperative } \\
\text { change }\end{array}$ & $45.74 \mathrm{D}$ & \\
\hline
\end{tabular}


After wedge resection, 19 corneas showed a more than $45^{\circ}$ shift in their axis of astigmatism; these were considered overcorrected. After the procedure, the best corrected visual acuity with spectacles or contact lenses improved in 25 eyes, deteriorated in 2 eyes, showed no change in 12 eyes, and was unknown in 2 eyes.

No major complications were encountered during surgery or during follow-up in any of the 40 patients. Two patients were regrafted 1.5 and 2.5 years after a prior lamellar and penetrating keratoplasty respectively, in one patient due to interface opacities after a lamellar graft and in the other due to recurrent herpetic keratitis. Three patients required a subsequent surgical procedure to reduce residual corneal astigmatism. One patient with a thin corneal recipient underwent a successful second wedge resection after 6.5 years. A complementary relaxing incision in the steepest axis was successfully performed in 2 patients with interstitial keratitis after 3 and 7 months. In these 2 patients the residual astigmatism before this second procedure amounted to 10 and 9 diopters, respectively.

\section{Long-term results}

Sixteen patients had a follow-up of less than 3 years because they had not reached this postexamination period, were lost to follow-up or had died. Twenty-four patients (with 25 wedge resections) were observed for 3 years or more. The follow-up period of 14 patients ( 15 wedge resections) was 5 years or more. Nine patients were followed for 10 years or more. The preoperative astigmatism and the course of the postoperative astigmatism of these patients are presented in Table 3 . The results show that during the various follow-up periods the corneal astigmatism hardly changed in 15 out of 24 patients, corresponding with 16 out of 25 cases of wedge resections. However, in 6 patients, 5 with keratoconus and 1 with Fuchs' dystrophy, the astigmatism gradually increased over the years (Table 3 : case 4, 10, 18, 21, 22 and 23). The inexplicable development of astigmatism in patient 4 with keratoconus is shown from the time of the penetrating keratoplasty up to the present (Table 4). In the remaining 3 patients, 2 with herpetic keratitis and 1 with radial keratotomy, the astigmatism gradually decreased over the years (Table 3: case 2, 9 and 19).

The axis of the keratometry readings hardly changed in 21 out of 25 cases of wedge resections during the follow-up period (range of axis shift was 0 to $25^{\circ}$ ). In 4 patients, all of whom suffered from keratoconus, the axis of astigmatism changed $45^{\circ}$ or more over the years (case $3: 80^{\circ}$; case $4: 50^{\circ}$; case 11: $55^{\circ}$; case $24: 45^{\circ}$ ). In 3 of these patients, however, the astigmatism remained stable at a low level. 


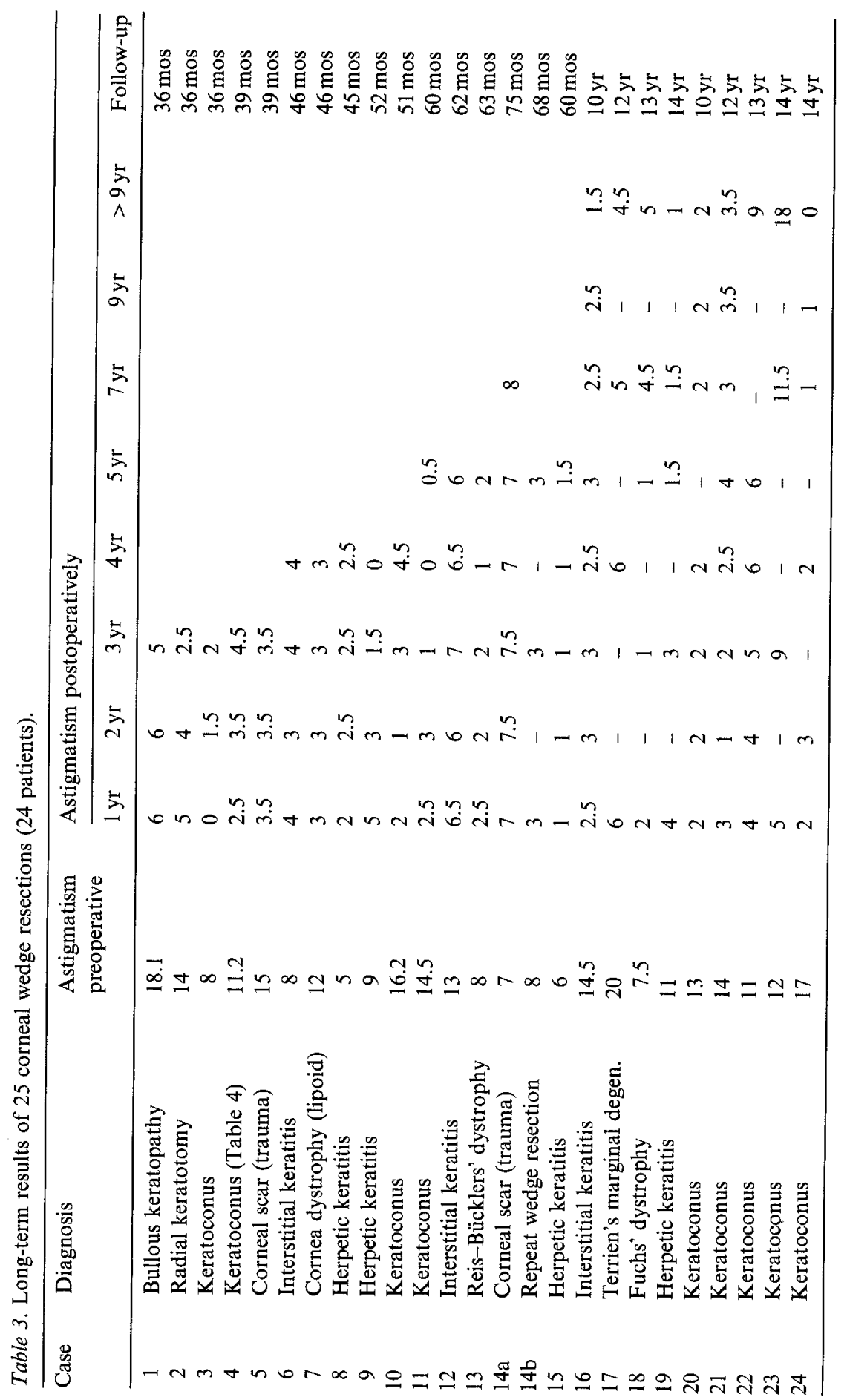




\section{Comment}

After penetrating keratoplasties, corneal astigmatism is a common problem that perplexes both clinician and patient. Surgical corrections of severe astigmatism by various microsurgical techniques have been described [1-15]. The most important are relaxing incisions, with or without compression sutures, and corneal wedge resections.

The corneal wedge resection technique for management of postkeratoplasty astigmatism has been described by Troutman [1] and others (Table 5). The effect of a wedge resection on the cornea is that it steepens the flatter curvature, but also flattens the steeper opposite one [17]. Wedge resections provide a graded control of astigmatic correction through selective keratometric-controlled suture removal, which is an important advantage. Occasionally, irregular astigmatism develops after a wedge resection, especially when irregular or wide wedges are cut.

In our study the keratometric astigmatism decreased from an average of 11.7 diopters preoperatively to 3.5 diopters postoperatively, a reduction of 8.2 diopters or $70 \%$. These findings are comparable to the previously reported data on wedge resections (Table 5). An average final cylinder of $3.5 \mathrm{D}$ after wedge resection compares favorably with published averages of 2.5 to 5.0 diopters after uncomplicated penetrating keratoplasty [18-20]. After wedge resection, the mean change in spherical equivalent measured by keratometry was a hyperopic shift of $1.02 \mathrm{D}$. Other studies reported either an almost unchanged spherical equivalent $[8,11]$ or a trend toward a more

Table 4. Postoperative follow-up of Astigmatism after Penetrating Keratoplasty (PKP) and Wedge Resection in patient 4 with a keratoconus.

\begin{tabular}{lcc}
\hline $\begin{array}{l}\text { Follow-up } \\
\text { (postoperative) }\end{array}$ & $\begin{array}{l}\text { Astigmatism } \\
\text { in diopters }\end{array}$ & $\begin{array}{l}\text { Steepest } \\
\text { meridian }\end{array}$ \\
\hline$P K P$ & & \\
1 year & 3 & $120^{\circ}$ \\
2 years & 4 & $110^{\circ}$ \\
5 years & 6 & $120^{\circ}$ \\
10 years & 6 & $115^{\circ}$ \\
14 years & 11 & $120^{\circ}$ \\
16 years & 11.2 & $120^{\circ}$ \\
Wedge resection & & \\
6 months & 1.5 & $110^{\circ}$ \\
1 year & 2.5 & $110^{\circ}$ \\
2 years & 3.5 & $120^{\circ}$ \\
3 years & 4.5 & $115^{\circ}$ \\
\hline
\end{tabular}


myopic spherical equivalent $[3,9]$. The small change suggests that the corneal wedge resection does not alter the ametropia consistently, i.e., it creates a reasonably predictable myopic or hyperopic postoperative shift. The amount of steepening of the flat meridian or flattening of the steeper meridian, as well as the direction of the ametropic change, appear to be less predictable for individual cases (range of postoperative shift: -6.45 to $+5.39 \mathrm{D})$.

In many publications the results of wedge resections have been described with a short follow-up [8-11]. These suggest that the keratometric readings are stable in the period between 6 months and 3 years after surgical correction. The purpose of our study was to examine the stability of the keratometric readings after wedge resection in the long run. In 19 out of 25 corneas the keratometric astigmatism remained practically stable or decreased over the years. However, in 6 patients with varying follow-up periods the astigmatism gradually increased over the years (Table 3). In 2 keratoconic patients with a follow-up of 39 and 51 months the astigmatism increased from 1.5 to 4.5 and from 1 to 4.5 diopters, respectively. It will be interesting to watch these patients in the years to come. In a patient with Fuchs' dystrophy the astigmatism remained stable for 5 years, then showed an increase of 4 diopters during the next 8 years. In a keratoconic eye the astigmatism increased from 1 to 4 diopters in 3 years, then remaining stable. In 2 other patients, who underwent penetrating keratoplasty for keratoconus, the astigmatism gradually increased by 5 and 14 diopters in the course of 13 and 14 years respectively (Table 3 ).

Table 5. Previously published results of corneal wedge resections.

\begin{tabular}{|c|c|c|c|c|c|}
\hline \multirow[t]{2}{*}{ Authors } & \multirow{2}{*}{$\begin{array}{l}\text { Number of } \\
\text { wedge } \\
\text { resections }\end{array}$} & \multicolumn{3}{|c|}{$\begin{array}{l}\text { Average keratometric astigmatism } \\
\text { (diopters) }\end{array}$} & \multirow{2}{*}{$\begin{array}{l}\text { Follow-up } \\
\text { period } \\
\text { (+ range) }\end{array}$} \\
\hline & & $\begin{array}{l}\text { preoperative } \\
(+ \text { range })\end{array}$ & $\begin{array}{l}\text { postoperative } \\
(+ \text { range) }\end{array}$ & $\begin{array}{l}\text { change } \\
(+ \text { range })\end{array}$ & \\
\hline Troutman [9] & 10 & $\begin{array}{l}11.50 \mathrm{D} \\
(9.00-16.00)\end{array}$ & $\begin{array}{l}3.83 \mathrm{D} \\
(2.00-6.00)\end{array}$ & $\begin{array}{l}7.67 \mathrm{D} \\
(3.00-11.5)\end{array}$ & $?$ \\
\hline $\begin{array}{l}\text { Krachmer and } \\
\text { Frenzl }[8]\end{array}$ & 10 & $\begin{array}{l}11.50 \mathrm{D} \\
(5.75-18.00)\end{array}$ & $\begin{array}{l}4.75 \mathrm{D} \\
(1.75-7.00)\end{array}$ & $\begin{array}{l}6.75 \mathrm{D} \\
(2.75-16.25)\end{array}$ & $\begin{array}{l}16 \mathrm{mos} \\
(4-43)\end{array}$ \\
\hline Dutescu et al. [12] & 8 & $\begin{array}{l}10.4 \mathrm{D} \\
(8.0-12.0)\end{array}$ & $\begin{array}{l}4.13 \mathrm{D} \\
(3.00-5.75)\end{array}$ & $\begin{array}{c}6.3 \mathrm{D} \\
(4.3-8.5)\end{array}$ & $\begin{array}{c}? \\
(5-60)\end{array}$ \\
\hline Lugo et al. [11] & 14 & $\begin{array}{l}9.29 \mathrm{D} \\
(3.00-17.00)\end{array}$ & $\begin{array}{l}5.54 \mathrm{D} \\
(0.50-14.00)\end{array}$ & $\begin{array}{l}3.75 \mathrm{D} \\
(0.50-11.00)\end{array}$ & $\begin{array}{l}17 \mathrm{mos} \\
(5-35)\end{array}$ \\
\hline Present study & 41 & $\begin{array}{l}11.7 \mathrm{D} \\
(5.0-22.5)\end{array}$ & $\begin{array}{l}3.5 \mathrm{D} \\
(0-10.0)\end{array}$ & $\begin{array}{l}8.2 \mathrm{D} \\
(0-16.5)\end{array}$ & $\begin{array}{l}11 \mathrm{mos} \\
(5-24)\end{array}$ \\
\hline
\end{tabular}


In these 6 patients, who had undergone penetrating keratoplasty, the progress of the astigmatism is difficult to explain. It has been shown that in $64 \%$ of keratoconic cases the astigmatism after penetrating keratoplasty correlates well with the preoperative Placido axis [21]. In keratoconus not only the centre but also the periphery of the cornea may be involved. Moreover, some authors suggest that the distortion may involve the sclera, peripheral to the cornea as well [21, 22]. Therefore, a built-in astigmatism seems to be present in the recipient cornea and sclera, which largely determines the axis and degree of astigmatism after penetrating keratoplasty and astigmatism correction. The cornea may therefore resume its original, preoperative shape. It may well be that built-in astigmatism or the progression of the disease in the recipient cornea and sclera explains the gradual increase of astigmatism over the years in our keratoconic eyes.

In recent years corneal relaxing incisions have gained popularity in the management of high postsurgical astigmatism [1-8]. The use of relaxing incisions in the steep axis is a simple technique with fairly rapid visual rehabilitation. It corrects small amounts of astigmatism and can be repeated if necessary $[4,5,8]$. The amount of correction, however, is unpredictable [3-6], and the risk of wound dehiscence, graft instability and corneal perforation must be considered [3-6, 8]. Recently, Limberg et al. described the use of compression sutures alone for the reduction of astigmatism after penetrating keratoplasty [15]. The astigmatism was reduced by only $4.8 \mathrm{D}$ on average 9 to 12 months after surgery.

For the correction of high astigmatism, we still prefer wedge resection, because wedge resection is capable of correcting greater amounts of astigmatism and because the results are reasonably predictable. In most of our patients, who had had penetrating keratoplasty, the corneas showed graft elevation or wound dehiscence before or after removal of the running suture. If this is discovered early, resuturing with or without opening of the wound is the better technique. In our opinion however, if many months have passed, a small wedge resection should be performed where the transplant has loosened or become slightly elevated. It is important to instruct the patients to return to the office if their vision changes substantially after suture removal, because resuturing is much easier to perform shortly after the graft elevation or wound dehiscence has occurred.

In this study we found stable keratometry readings after wedge resections in the majority of our patients. The astigmatism gradually increased in 6 patients, 5 with keratoconus and 1 with Fuchs' dystrophy. 


\section{References}

1. Troutman RC. Microsurgery of the Anterior Segment of the Eye, Vol 2. St Louis: Mosby 1977; 263-286.

2. Troutman RC, Swinger C. Relaxing incision for control of postoperative astigmatism following keratoplasty. Ophthalmic Surg 1980; 11: 117-120.

3. Lindstrom RL, Lavery GW. Correction of post-keratoplasty astigmatism. In: Sanders DR, Hofmann RF, Salz JJ (eds): Refractive Corneal Surgery. Thorofare, New Jersey, SLACK 1986; 215-240.

4. Lavery GW, Lindstrom RL, Hofer LA, Doughman DJ. The surgical management of corneal astigmatism after penetrating keratoplasty. Ophthalmic Surg 1985; 16: 165-169.

5. Sugar J, Kirk AK. Relaxing keratotomy for post-keratoplasty high astigmatism. Ophthalmic Surg 1983; 14: 156-158.

6. Lindstrom RL, Lindquist TD. Surgical correction of postoperative astigmatism. Cornea 1988; 7: 138-148.

7. Troutman RC. Corneal wedge resections and relaxing incisions for postkertoplasty astigmatism. Int Ophthalmol Clin 1983; 23: 161-168.

8. Krachmer JH, Fenzl RE. Surgical correction of high postkeratoplasty astigmatism. Relaxing incisions vs wedge resection. Arch Ophthalmol 1980; 98: 1400-1402.

9. Troutman RC. Microsurgical control of corneal astigmatism in cataract and keratoplasty. Trans Am Acad Ophthalmol Otolaryngol 1973; 77: 563-572.

10. Van Rij G, Vijfvinkel G. Correction of postkeratoplasty astigmatism by Razor blade and V-shaped knife wedge resection. Ophthalm Surg 1983; 14: 406-410.

11. Lugo M, Donnenfeld ED, Arentsen JJ. Corneal wedge resection for high astigmatism following penetrating keratoplasty. Ophthalmic Surg 1987; 18: 650-653.

12. Dutescu, M, Reim M, Schmidt-Martens FW. Operative Korrektur des starken Astigmatismus nach Keratoplastik. Klin Monatsbl Augenheilkd 1983; 182: 191-195.

13. Mandel MR, Shapiro MB, Krachmer JH. Relaxing incisions with augmentation sutures for the correction of postkeratoplasty astigmatism. Am J Ophthalmol 1987; 103: 441-447.

14. McCartney DL, Whitney CE, Stark WJ, Wong SK, Bernitsky DA. Refractive keratoplasty for disabling astigmatism after penetrating keratoplasty. Arch Ophthalmol 1987; 105: 954-957.

15. Limberg MB, Dingeldein SA, Green MT, Klyce SD, Insler MS, Kaufman HE. Corneal compression sutures for the reduction of astigmatism after penetrating keratoplasty. Am J Ophthalmol 1989; 108: 36-42.

16. Vijvinkel G, Van Loenen Martinet AHJ. Contact keratoscope for clinical and surgical use. Int Ophthalmol 1981; 4: 177-178.

17. Van Rij G, Waring III GO. Changes in corneal curvature induced by sutures and incisions. Am J Ophthalmol 1984; 98: 773-783.

18. Binder PS. The effect of suture removal on postkeratoplasty astigmatism. Am J Ophthalmol 1988; 105: 637-645.

19. Musch DC, Meyer RF, Sugar A, Soong HK. Corneal astigmatism after penetrating keratoplasty: the role of suture technique. Ophthalmology 1989; 96: 698-703.

20. Binder PS. Selective suture removal can reduce postkeratoplasty astigmatism. Ophthalmology 1985; 92: 1412-1416.

21. Pallikaris I. Die präoperative Placidophotographie bei Keratokonus und ihre Bedeutung im Zusammenhang mit dem postoperativen Astigmatismus. Graefes Arch Klin Exp Ophthalmol 1980; 213: 87-99. 
22. Troutman RC. Astigmatic considerations in corneal graft. Ophthalmic Surg 1979; 10: 21-26.

Address for correspondence: G. van Rij, MD, PhD, Department of Ophthalmology, University of Groningen, P.O. Box 30.001, 9700 RB Gruningen, The Netherlands. 